\title{
RADIATION TOXICITY IN PROSTATE CANCER PATIENTS
}

\section{TOKSIČNOST RADIOTERAPIJE KOD PACIJENATA SA KARCINOMOM PROSTATE}

\author{
Jelena Stanić ${ }^{1,2}$, Vesna Stanković ${ }^{1}$, Marina Nikitović ${ }^{1,2}$
}

${ }^{1}$ Institut za onkologiju i radiologiju Srbije, Beograd, Srbija

${ }^{2}$ Univerzitet u Beogradu, Medicinski fakultet, Beograd, Srbija

Correspondence: simicans@gmail.com

\begin{abstract}
Prostate cancer (PC) is the most frequent male tumor, accounting for about one-third of all cancers in men. Since survival is often favorable regardless of therapy, treatment decisions may depend on therapy-specific health outcomes. The majority of men initially diagnosed with localized PC ultimately die with, rather than of, their disease. As a result, men who are diagnosed will live many years with the treatment's sequelae.

The major therapeutic strategies include radical prostatectomy or external beam radiotherapy. Radiotherapy is one of the curative treatment options. The tumor dose-response relationship has been studied and is widely accepted. The unsatisfactory local control with doses $<70$ Gy led to dose escalation using highly precise radiotherapy techniques - three-dimensional conformal radiotherapy and intensity-modulated radiotherapy enabling the delivery of high radiation doses up to $74-78 \mathrm{~Gy}$.

Bowel, rectal and urinary toxicities are the principal limiting factors in delivering a high dose. Acute symptoms include a change in bowel habits, urgency, and fecal incontinence. The most commonly reported late toxicities were chronic diarrhea, proctitis, or rectal bleeding. Several factors have been associated with increased gastrointestinal toxicity such as larger bowel volume receiving high doses, the patient's age, diabetes, and concomitant use of androgen deprivation therapy.

Bladder damage resulting from acute radiation toxicity is manifested as radiation cystitis (frequent urination and dysuric disorders). Smoking, previous abdominopelvic surgeries and the use of diuretics significantly affect the occurrence of acute genitourinary toxicity grade $\geq 2$. Risk factors for the development of late genitourinary complications are higher radiation dose, previous urinary problems, transurethral interventions, and acute genitourinary complications.

It is essential to strike a balance between the therapeutic benefits and radiotherapy side effects. Severe late complications significantly reduce the quality of life (QOL) of PC survivors. Early detection and proper evaluation of complications are especially important in increasing the patient's QOL.
\end{abstract}

Keywords:

prostate

cancer,

radiotherapy,

radiation

toxicity 


\section{Sažetak}

Karcinom prostate je najčešći tumor u muškoj populaciji, čineći približno trećinu svih karcinoma. Budući da je preživljavanje često dugogodišnje, bez obzira na primenjenu terapiju, odluke o lečenju mogu zavisiti od potencijalnih komplikacija specifičnih za terapiju. Većina pacijenata kojima je dijagnostikovan lokalizovani rak prostate na kraju umire sa, a ne zbog svoje bolesti. Kao rezultat, pacijenti kojima je dijagnostikovan rak prostate živeće mnogo godina sa posledicama svog specifičnog onkološkog lečenja.

Glavne terapijske strategije uključuju radikalnu prostatektomiju ili transkutanu radioterapiju. Radioterapija je jedna od opcija kurativnog lečenja. Odnos doze zračenja i tumorskog odgovora na terapiju je široko i detaljno proučavan i prihvaćen. Zapravo, nezadovoljavajuća lokalna kontrola bolesti sa dozama $<70$ Gy dovela je do studija eskalacije doze i primene visoko preciznih radioterapijskih tehnika kao što su trodimenzionalna konformalna radioterapija i intenzitetom modulisana radioterapija, omogućavajući aplikovanje visokih doza zračenja na prostatu od 74 do 78 Gy.

Urinarna i toksičnost tankog creva i rektuma glavni su ograničavajući faktori u isporuci visoke radioterapijske doze. Simptomi tokom lečenja uključuju promenu u navikama pražnjenja creva, hitnost u pražnjenju i fekalnu inkontinenciju. Najčešće kasne sekvele su hronična dijareja, proktitis ili rektalno krvarenje. Nekoliko faktora je povezano sa povećanom gastrointestinalnom toksičnošću - veća zapremina creva koja prima velike doze zračenja, starost pacijenta, dijabetes i istovremena upotreba androgen deprivacione terapije. Oštećenje mokraćne bešike, indukovano zračenjem, manifestuje se kao radijacioni cistitis (često mokrenje i dizurični poremećaji). Pušenje, prethodne abdominalne operacije i upotreba diuretika značajno utiču na pojavu akutne genitourinarne toksičnosti stepena $\geq 2$. Faktori rizika za razvoj kasnih genitourinarnih komplikacija su veće doze zra-

Ključne reči:

karcinom

prostate,

radioterapija,

radijaciona

toksičnost čenja, prethodni urinarni problemi, transuretralne intervencije i akutne genitourinarne komplikacije.

Izuzetno je značajno uspostaviti ravnotežu između potencijalne koristi i neželjenih efekata radioterapije. Ozbiljne kasne komplikacije značajno smanjuju kvalitet života dugoživećih pacijenata sa karcinomom prostate. Rano otkrivanje i pravilna procena terapijskih komplikacija, kao i personalizovani pristup terapiji zbog toga su posebno važni.

\section{Uvod}

Produženje očekivanog trajanja životnog veka čoveka primećeno je na svetskom nivou tokom protekle decenije (1). To nameće velike izazove globalnom zdravlju, jer se neke bolesti, poput karcinoma prostate, javljaju sa porastom životne dobi (2). Prevalencija raka prostate povećava se sa svakom decenijom života, te je u publikovanim studijama obdukcije utvrđeno da je $5 \%$ muškaraca mladih od 30 godina i $59 \%$ starijih od 79 godina imalo karcinom prostate (3). Rak prostate je, posle raka pluća, najčešći maligni tumor u muškoj populaciji i drugi najčešći uzrok mortaliteta od malignih bolesti kod muškaraca (4). Globalna učestalost karcinoma prostate raste $\mathrm{u}$ većini zemalja, a povećanja su najuočljivija u Sjedinjenim Američkim Državama, Severnoj i Zapadnoj Evropi. Prijavljena incidencija je veća u zemljama sa višim socioekonomskim razvojem (5).

Lečenje pacijenata sa rakom prostate je multidisciplinarno i podrazumeva više terapijskih opcija: radikalnu prostatektomiju (RP), radioterapiju (RT) i/ili hormonsku terapiju (engl. Androgen deprivation therapy, ADT). $\mathrm{O}$ modalitetu lečenja se odlučuje na osnovu stadijuma bolesti, histopatoloških karakteristika tumora, potencijalne koristi, kao i mogućih neželjenih efekata svake od terapijskih opcija. Pored starosti i prisustva komorbiditeta,socioekonomskistatus pacijentaitrendoviu kliničkojpraksirazličitihmedicinskih centara(bezobzirana stadijum bolesti) igraju važnu ulogu u odabiru odgovarajuće terapije (6). Većina obolelih od karcinoma prostate ima očekivano dugogodišnje preživljavanje nakon postavljanja dijagnoze. Određeni broj, međutim nikada neće razviti morbiditet niti umreti od komplikacija koje se mogu pripisati samom toku osnovne bolesti. Stoga je procena kratkoročnih i dugoročnih negativnih sekvela lečenja od velike važnosti.

Radioterapija predstavlja značajan terapijski modalitet u lečenju karcinoma prostate koji pruža stope izlečenja uporedive sa stopama RP. Iako ishodi lečenja mogu biti slični, radioterapija ima svoj jedinstven skup neželjenih efekata. Pored toga, profili komplikacija samog radioterapijskog tretmana razlikuju se u zavisnosti od načina aplikovanja zračenja, tj. od udaljenosti izvora zračenja od površine tela, te se radioterapija može sprovoditi iz neposredne blizine (intersticijalna brahiterapija) ili sa određene udaljenosti od površine tela - transkutana zračna terapija (engl. External beam radiotherapy, EBRT) (7). Danas se više od trećine muškaraca sa lokalizovanim karcinomom prostate leči primenom EBRT (8). 
Transkutana radioterapija

Transkutana zračna terapija predstavlja primenu visokoenergetskog jonizujućeg X-zračenja, proizvedenog u aparatu koji se zove linearni akcelerator. Glava akceleratora se rotira oko pacijenta, omogućavajući zračnom snopu više uglova ulaska. Rezultirajući efekat je presek više zračnih snopova u određenom ciljnom volumenu u telu pacijenta (slika 1) (9). snopova obezbedila odgovarajuća totalna doza (engl. Total dose, TD) zračenja na mestima bolesti, a smanjila doza na susedne normalne strukture. Da bi se prostata primenom radioterapije adekvatno tretirala i okolni organi će se, po potrebi, naći unutar zračnog volumena. Vrat mokraćne bešike, bulbus penisa i prednji rektalni zid dobijaju značajne doze zračenja. Pored toga, uretra prostate i neurovaskularni snopovi ulaze u zračno polje. Konačno, ako su i karlični limfni nodusi uključeni u zračni volumen, cela mokraćna

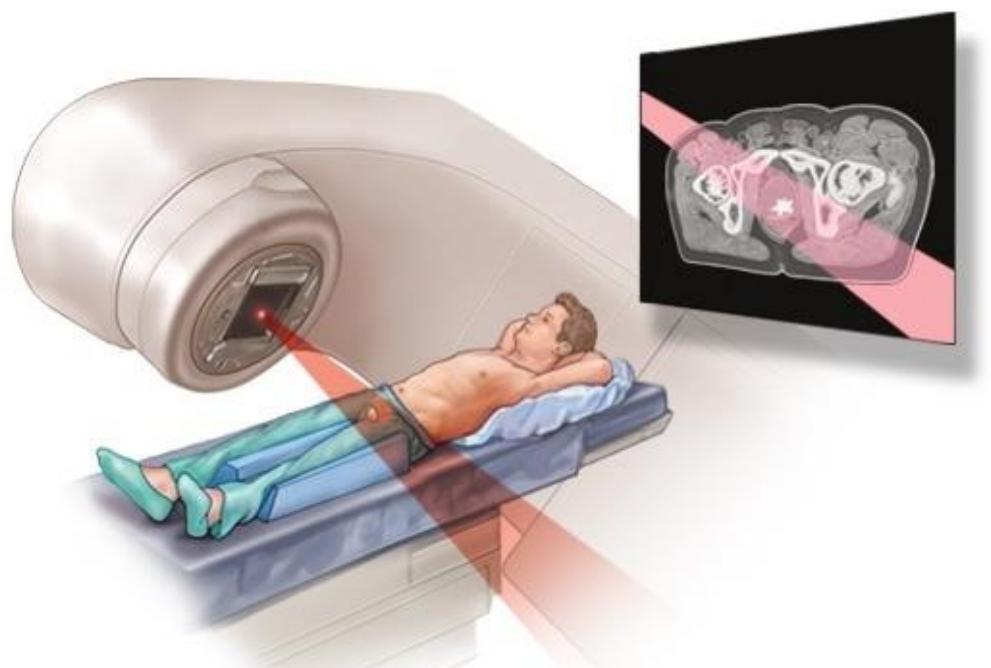

Slika 1. EBRT kod karcinoma prostate. Izvor: Mynderse A. L, Cummings T, King A. M, McDaniel K, Srnka C. Mayo Clinic Essential Guide to Prostate Health. 2015.

Kontinuirani napredak u planiranju radioterapije kompjuterizovanom tomografijom (engl. Computerized tomography, CT) doveo je do razvoja trodimenzionalne konformalne radioterapije (engl. Three-dimensional conformal radiotherapy, 3D-CRT) u odnosu na konvencionalnu $2 D$ radioterapiju koja se izvodi na osnovu jednog $C T$ preseka, tj. u dve dimenzije ( $2 D$ planiranje). Kod $3 D$-CRT, planiranje zračenja počinje $C T$ skeniranjem pacijenta, te se na osnovu serije CT preseka i njihovom rekonstrukcijom u sistemu za planiranje dobija $3 D$ anatomski model, tzv. "virtuelni pacijent", koji omogućava lekaru - radijacionom onkologu, da mapira prostatu, semene vezikule i drenirajuće limfne noduse kako bi se u najboljem rasporedu zračnih bešika, rektum, sigmoidno debelo crevo i tanko crevo dobijaju dodatne doze. Anatomija karlice diktira morbiditet, tj. neželjene efekte radioterapije $(7,10,11)$.

Danas se visokokonformalna EBRT, kao što je intenzitetom modulirana radioterapija (engl. Intensitymodulated radiotherapy, IMRT) i zapreminski modulirana rotaciona terapija (engl. Volume-modulated arc therapy, VMAT) koriste kao zlatni standard u lečenju karcinoma prostate. Obe tehnike pružaju složenu raspodelu doze unutar ciljnog volumena i omogućavaju eskalaciju doze, bolju poštedu okolnog zdravog tkiva, bolju lokalnu kontrolu bolesti i nižu stopu morbiditeta (slika 2).

Preporučene doze za grupu pacijenata sa niskim

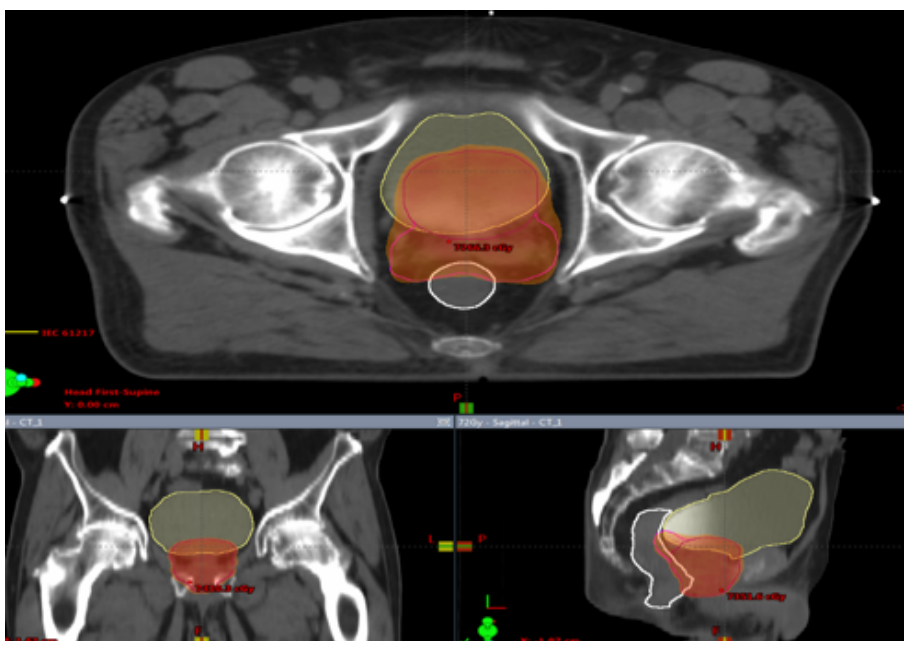

Slika 2. 3D projekcija ciljnog volumena - prostate i semenih vezikula i susednih normalnih struktura - rektuma i mokraćne bešike, kod IMRT lokalizovanog karcinoma prostate, materijal Instituta za onkologiju i radiologiju Srbije. 
Stanić J. et al. Toksičnost radioterapije kod pacijenata sa karcinomom prostate. MedPodml 2021, 72(2):26-33

Tabela 1. RTOG skoring kriterijumi za akutna radijaciona oštećenja

\begin{tabular}{|c|c|c|c|c|}
\hline Organ & Gr I & Gr II & Gr III & Gr IV \\
\hline $\begin{array}{l}\text { Genitourinarni } \\
\text { trakt }\end{array}$ & $\begin{array}{l}\text { Učestalo mokrenje i } \\
\text { nokturija do } 2 x \text { češće } \\
\text { nego pre tretmana, } \\
\text { dizurične smetnje koje } \\
\text { ne zahtevaju lečenje }\end{array}$ & $\begin{array}{l}\text { Učestalo mokrenje } \\
\text { i nokturija koja nije } \\
\text { češća od } 1 \mathrm{x} / 1 \mathrm{~h} \text {, dizurija } \\
\text { i/ili urgencija, spazam } \\
\text { bešike koji zahteva } \\
\text { lokalni anestetik }\end{array}$ & $\begin{array}{c}\text { Učestalo mokrenje i } \\
\text { nokturija koja je češća od } \\
\text { 1x/1h, dizurija, urgencija, } \\
\text { spazam bešike, karlični bol } \\
\text { koji zahteva analgetike }\end{array}$ & $\begin{array}{c}\text { Hematurija } \\
\text { koja zahteva } \\
\text { transfuziju, } \\
\text { opstrukcija bešike, } \\
\text { ulceracije ili } \\
\text { nekroza }\end{array}$ \\
\hline
\end{tabular}

Gubitak težine do

Gornji

gastrointestinalni

trakt
$5 \%$ u odnosu na pre tretmana, mučnina koja ne zahteva antiemetike, abdominalni diskomfor koji ne zahteva lekove
Gubitak težine do $15 \%$ u odnosu na pre tretmana, mučnina sa povraćanjem koja zahteva antiemetike, abdominalni bol koji zahteva lekove
Gubitak težine više od 15\% u odnosu na pre tretmana, mučnina sa povraćanjem i pored antiemetika, abdominalni bol i pored lekova, hematemeza, melena, abdominalna distenzija
Ileus, perforacija,

GI krvarenje

koje zahteva transfuziju
Donji gastrointestinalni trakt
Učestale stolice koje ne zahtevaju terapiju, abdominalni diskomfor koji ne zahteva lečenje
Učestale stolice koje zahtevaju terapiju, zahtevaju lečenje
Dijareja koja zahteva parenteralnu nadoknadu, pojava krvi i sluzi u stolici, distenzija trbuha
Akutna i subakutna opstrukcija, fistula i perforacija, GI krvarenje koje zahteva transfuziju

Tabela 2. RTOG skoring kriterijumi za kasna radijaciona oštećenja

\begin{tabular}{|c|c|c|c|c|}
\hline Organ & Gr I & Gr II & Gr III & Gr IV \\
\hline $\begin{array}{l}\text { Genitourinarni } \\
\text { trakt }\end{array}$ & $\begin{array}{l}\text { Učestalo mokrenje i } \\
\text { nokturija do } 2 x \text { češće } \\
\text { nego pre tretmana, } \\
\text { dizurične smetnje koje } \\
\text { ne zahtevaju lečenje }\end{array}$ & $\begin{array}{l}\text { Učestalo mokrenje } \\
\text { i nokturija koja nije } \\
\text { češća od } 1 \mathrm{x} / 1 \mathrm{~h} \text {, dizurija } \\
\text { i/ili urgencija, spazam } \\
\text { bešike koji zahteva } \\
\text { lokalni anestetik }\end{array}$ & $\begin{array}{c}\text { Učestalo mokrenje i } \\
\text { nokturija koja je češća } \\
\text { od } 1 \mathrm{x} / 1 \mathrm{~h} \text {, dizurija, } \\
\text { urgencija, spazam bešike, } \\
\text { karlični bol koji zahteva } \\
\text { analgetike }\end{array}$ & $\begin{array}{l}\text { Hematurija koja } \\
\text { zahteva transfuziju, } \\
\text { opstrukcija bešike, } \\
\text { ulceracije ili nekroza }\end{array}$ \\
\hline
\end{tabular}

\section{Gubitak težine}

do $5 \%$ u odnosu

Gornji gastrointestinalni trakt

\section{na pre tretmana,} mučnina koja ne zahteva antiemetike, abdominalni diskomfor koji ne zahteva lekove

\section{Gubitak težine do} $15 \%$ u odnosu na pre tretmana, mučnina sa povraćanjem koja zahteva antiemetike, abdominalni bol koji zahteva lekove
Gubitak težine više od $15 \%$ u odnosu na pre tretmana, mučnina sa povraćanjem i pored antiemetika, abdominalni bol i pored lekova, hematemeza, melena, abdominalna distenzija
Ileus, perforacija, GI krvarenje koje zahteva transfuziju

\section{Donji} gastrointestinalni trakt
Učestale stolice koje ne zahtevaju terapiju, abdominalni diskomfor koji ne zahteva lečenje
Učestale stolice koje zahtevaju terapiju, abdominalni bolovi koji zahtevaju lečenje
Dijareja koja zahteva parenteralnu nadoknadu, pojava krvi i sluzi u stolici, distenzija trbuha
Akutna i subakutna opstrukcija, fistula i perforacija, GI krvarenje koje zahteva transfuziju 
rizikom za relaps su u rasponu od TD 72 Gy do preko 80 Gy, standardnim režimom frakcionisanja $(1,8-2$ Gy dnevno, 5 dana u nedelji). U grupi sa srednjim rizikom preporučene doze su istog opsega kao u grupi sa niskim rizikom, uz dodatak $A D T$ tokom 4 - 6 meseci. Porast doze u ovoj grupi dovodi do boljih rezultata lečenja, a prema Evropskom urološkom udruženju (engl. European Association of Urology, EAU) najniža preporučena doza je $76 \mathrm{~Gy}$. Za visoko rizičnu grupu preporučuje se povećanje doze i dugotrajna upotreba $A D T$, obično 2 - 3 godine $(6,10)$.

\section{Toksičnost radioterapije}

U evaluaciji ukupnog efekta radioterapijskog lečenja, osim procene postizanja lokalne kontrole bolesti, neophodno je evaluirati i radijacionu toksičnost, tj. komplikacije. Intenzitet simptoma zavisi od aplikovane doze, zračnog volumena, režima frakcionisanja, modaliteta radioterapijskog lečenja i osetljivosti tkiva koja se zrače.

Hronološki, radioterapijske komplikacije su podeljene na:

a) akutne (rane) komplikacije - javljaju se tokom zračenja i 4 - 6 nedelja po okončanju RT, odnosno perzistiraju i do 120 dana od početka RT. Ove reakcije su ponekad vrlo izražene, obično su prolazne i manje je verovatno da će dovesti do trajnih oštećenja;

b) subakutne komplikacije - javljaju se u periodu od nekoliko nedelja do nekoliko meseci nakon zračenja;

c) kasne komplikacije - obično se manifestuju nakon nekoliko meseci, čak i nekoliko godina nakon zračenja. Ove promene su obično trajne (ireverzibilne). Onkogeneza sa pojavom tzv. sekundarnog maligniteta izazvanog zračenjem kasna je sekvela.

Kada govorimo o radioterapiji karcinoma prostate, najznačajnije su one koje dovode do pravljenja pauze $\mathrm{u}$ zračnom tretmanu, sa posledičnim produženjem ukupnog trajanja lečenja i/ili u manjoj ili većoj meri utiču na kvalitet života pacijenata. Najveći broj komplikacija se javlja u donjim partijama gastrointestinalnog (GI) i genitourinarnom (GU) traktu. Korišćenjem novih tehnika radioterapije, kao što su $3 D-C R T$, IMRT i VMAT, postignuta je veća preciznost u poređenju sa konvencionalnom tehnikom, što rezultira manje izraženim akutnim i kasnim komplikacijama, a zapremina okolnih struktura, tj. rektuma i mokraćne bešike koja je primala $95 \%$ propisane doze značajno je smanjena, sa apsolutnim smanjenjem od 23\%, odnosno $80 \%$ (11).

Iako se u kliničkoj praksi primenjuje veći broj protokola, još nije postignuta saglasnost o jedinstvenom sistemu kvantifikacije radioterapijske toksičnosti. Najčešće se koriste RTOG (engl. The Radiation Therapy Oncology Group) i EORTC (engl. The European Organisation for Research and Treatment of Cancer) šema za procenu morbiditeta na osnovu četiri parametra - SOMA (engl. Subjective, Objective, Management, Analytic) koji se odnose na subjektivne tegobe, objektivne znake bolesti, način sprovedenog lečenja i analizu funkcije lečenog tkiva pomoću objektivnih dijagnostičkih procedura (tabela 1 i 2) (12).

\section{Gastrointestinalne komplikacije}

Eskalacija doze je standard u lečenju karcinoma prostate radioterapijom. Konformalne radioterapijske tehnike (3D-CRT, IMRT, VMAT) omogućavaju isporuku doze $>70$ Gy na prostatu, uz redukciju doze na okolna, zdrava tkiva $(13,14)$. Rektum, međutim, ima tendenciju da bude dozno-limitirajuća struktura koja ograničava eskalaciju doze s obzirom na njegovu neposrednu blizinu. Rana i kasna toksičnost mogu se javiti kada rektum prima velike doze zračenja, tačnije rizik od pojave komplikacija je povećan kada su doze zračenja preko $72 \mathrm{~Gy}$.

Opisano je nekoliko faktora povezanih sa povećanom radijacionom toksičnošću creva i rektuma nakon $E B R T$ i oni uključuju zapreminu rektuma izloženu većim dozama zračenja, povećanje starosti pacijenta, istovremenu upotrebu $A D T$-a, prisustvo dijabetesa melitusa (DM), kao i inflamatorne bolesti creva (11).

Akutne GI komplikacije mogu biti vrlo izražene, ali obično imaju prolazni karakter i ređe dovode do pojave trajnih oštećenja. Ozbiljnost akutnih neželjenih efekata tokom radioterapije nalaže procenu i podršku pre, za vreme i nakon radioterapije. To je posebno važno u slučajevima kada se koristi eskalacija doze sa izmenjenim režimima frakcionisanja. Akutne gastrointestinalne komplikacije tokom zračne terapije mogu se manifestovati u vidu proktitisa ili enteritisa. Ovi simptomi uključuju dijareju, lažne pozive na stolicu (tenezme), hitnost pražnjenja, anorektalni bol, iritaciju hemoroida i krvarenje. Kontrolišu se antidijarealnim lekovima i/ili lokalnim antiinflamatornim preparatima. Stanje lokalne reakcije treba procenjivati na nedeljnom nivou. Nakon završetka RT, ovi simptomi se obično saniraju i povlače unutar 3 do 8 nedelja. Ozbiljnije akutne toksičnosti, međutim, izlažu pacijente većem riziku od dugotrajnih morbiditeta izazvanih radioterapijom (13). Multivarijantna analiza koju su sproveli Valdanji (Valdagni) i saradnici pokazala je da je srednja rektalna doza najznačajniji prediktivni faktor akutne toksičnosti donjeg GI trakta gradusa 2 - 3, po RTOG/EORTC kriterijumima, zajedno sa hemoroidima, upotrebom oralne antikoagulantne terapije (OAK)/antiagregacione terapije i androgenom deprivacijom. Krvarenje je bilo povezano sa hemoroidima, $A D T$ i srednjom dozom zračenja koju prima rektum. Učestalost stolice bila je povezana sa zračenjem semenih vezikula, primenom ADT duže od 3 meseca i procentualnim volumenom rektuma koji je primio više od 60 Gy (15). Stanković i saradnici su pokazali da su prisustvo hemoroida i hronična GI oboljenja statistički značajni prediktivni faktori za nastanak akutne GI toksičnosti (16). Multicentrična studija Vavasorija (Vavassori) i saradnika, sprovedena kod pacijenata sa lokalizovanim karcinomom prostate, lečenih primenom $3 D-C R T$, dozama $>70 \mathrm{~Gy}$, pokazala je da je najveći prediktivni značaj u razvoju akutne GI toksičnosti (gradus $\geq 2$ ) imala srednja rektalna doza, dok je primena OAK/antiagregacione terapije i hormonske terapije ispoljila protektivni efekat. Takođe je pokazano da je veći ozračeni volumen creva bio povezan sa povećanom učestalošću pražnjenja, tenezmima, 
inkontinencijom i krvarenjem. Hemoroidi su bili povezani sa većim rizikom od tenezama i krvarenja, a DM sa češćim javljanjem dijareja. Primena antihipertenzivne terapije je imala protektivni efekat na pojavu dijareja (17).

Kasne GI komplikacije se javljaju kod malog broja pacijenata i najčešće su manifestovane tenezmima, dijarejama, hematohezijama, rektalnim/analnim strikturama i inkontinencijom. Kasne komplikacije na tankom crevu nastaju u okviru od 1 do 15 godina nakon sprovedene radioterapije. Mogu se javiti fibroza i segmentne strikture tankog creva, mezenterijalne adhezije, zadebljali nabori sluznice i spazam sa izmenjenim vremenom pasaže, perzistentna dijareja, perforacije, enterokolična i enterovezikalna fistula. Malapsorpcioni sindrom je glavna sekvela kasnih postradijacionih komplikacija tankog creva. Rektalno krvarenje je najčešća kasna toksičnost, koja se generalno razvija usled neovaskularizacije i telangiektazija. Takođe može doći do zadebljanja i edema prednjeg zida rektuma (slika 3).

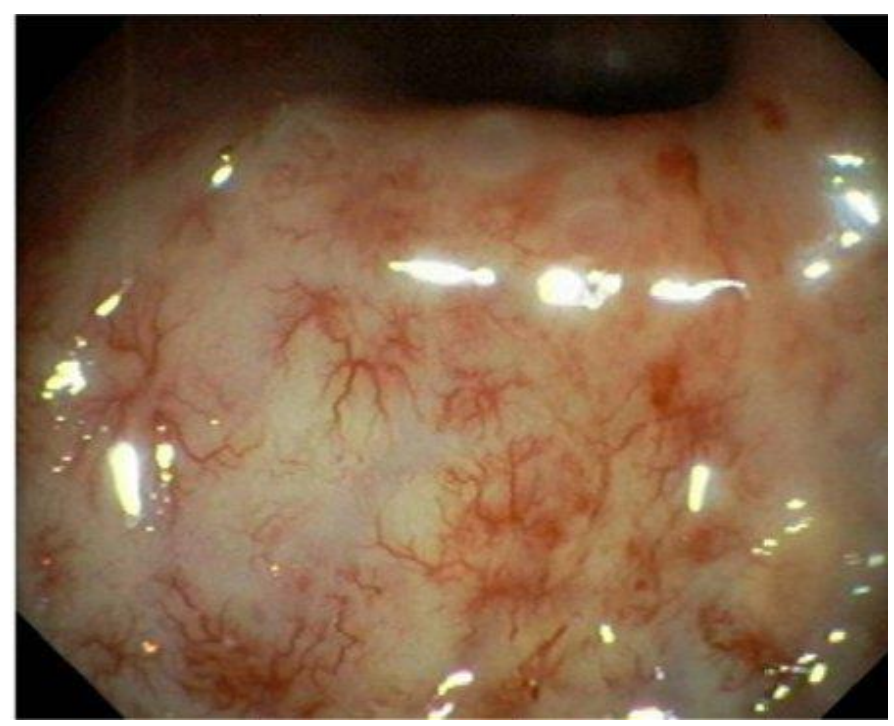

Slika 3. Primer radijacionog proktitisa pronađenog na endoskopiji. Postoje višestruke hemoragične promene i telangiektazije koje se vide nakon zračenja. Izvor: World Endoscopy Organization. Radiation proctitis; 2012.

Teško pogođeno crevo može postati fibrozno i ishemično, što rezultira ozbiljnijim kliničkim manifestacijama, poput formiranja fistule, strikture, gubitka usaglašenosti analnog sfinktera, pa čak i rektalne perforacije. Iako se kod malog broja pacijenata razvija krvarenje dovoljno ozbiljno da zahteva transfuziju, ono može ozbiljno poremetiti svakodnevne aktivnosti i negativno uticati na kvalitet života pacijenta $(11,13,18)$.

U randomizovanim kliničkim studijama koje su poredile dve grupe pacijenata sa karcinomom prostate koji su primili $68 \mathrm{~Gy}$, odnosno 78 Gy nisu primećene značajne razlike u pogledu kasne GI toksičnosti, osim rektalnog krvarenja (19). Studije su pokazale i da je starije životno doba i prisustvo gastrointestinalnih komorbiditeta (hemoroidi, polipi, divertikuloze) udruženo sa povećanim rizikom za razvoj kasnih GI komplikacija $(20,21)$.

\section{Urinarne komplikacije}

Urinarne komplikacije nakon primene zračne terapije kod pacijenata sa karcinomom prostate često se pripisuju povredi mokraćne bešike. Akutni simptomi urogenitalne toksičnosti (UGT), međutim, takođe mogu biti posledica radijacijom indukovane inflamacije prostate i prostatične uretre, što se može teško razlikovati od simptoma povrede mokraćne bešike. Još uvek nije poznato koji dozimetrijski parametri imaju najveći prediktivni značaj u nastanku UGT (22). Varijabilnost oblika i zapremine mokraćne bešike tokom samog radioterapijskog tretmana onemogućava precizno određivanje odnosa dozavolumen mokraćne bešike, koji bi predvideo nastanak UGT. Prospektivna studija eskalacije doze pokazala je da nema statistički značajne razlike u pojavi akutne i kasne UGT gradusa $\geq 2$, bez obzira na to da li je primenjena $3 D$-CRT ili $\operatorname{IMRT}(11,23)$.

Akutne urinarne komplikacije u najvećem broju slučajeva nastaju usled inflamacije indukovane radijacijom i odnose se na upalu i gubitak sluzokože u regiji vrata mokraćne bešike, u prostati i prostatičnom delu uretre. Simptomi se obično javljaju 2 do 3 nedelje nakon početka radioterapije, kada dolazi do narušavanja integriteta sluznice i traju nekoliko nedelja, dok se ne završi reepitelizacija. Mogu se javiti i iritativni i opstruktivni urinarni simptomi, sa tendencijom ka opstruktivnim kod muškaraca sa većim volumenom prostate (7). Pinkava (Pinkawa) i saradnici su u svojoj studiji govorili o akutnoj UGT kod 204 muškarca lečena dozama > 70 Gy sa posebnim naglaskom na zapreminu prostate pre tretmana. Neželjeni efekti su procenjivani po završetku lečenja, kao i nakon 2 i 12 meseci. Jedna trećina muškaraca prijavila je dizuriju, a $37 \%$ je prijavilo opstruktivne simptome po završetku lečenja. Do 2 meseca nakon tretmana, ovi simptomi su se vratili na početno stanje. I dizurija i opstruktivni simptomi bili su češći u grupi gde je zapremina prostate iznosila $>43$ $\mathrm{cm}^{3}$ (24). Pušenje, prethodne abdominopelvične operacije i upotreba diuretika značajno utiču na pojavu akutne genitourinarne toksičnosti stepena $\geq 2(11,25)$.

Kasne urinarne komplikacije nastaju nekoliko meseci ili godina nakon sprovedene radioterapije. One su rezultat promena na malim krvnim sudovima ozračenog tkiva koje dovode do hronične hipoksije, proređivanja sluzokože i aberantnog razvoja sudova (telangiektazija) (7). Najčešće manifestacije kasne UGT su uretralne strikture, bezbolna hematurija, čest, mada retko ozbiljan događaj, ili sindrom sličan hroničnom intersticijalnom cistitisu, manifestovan učestalim mokrenjem, dizurijom, pa čak i kontrakturom mokraćne bešike (26). Prijavljene stope strikture uretre su ispod $10 \%$, ali su veće kod muškaraca koji su prethodno imali transuretralnu resekciju (27). Kasne UGT gradusa 3 ili više pronađene su kod 7,7\% pacijenata sa samo $0,5 \%$ onih koji su imali morbiditet koji bi zahtevao veliku hiruršku intervenciju kao što je laparotomija, cistektomija ili produžena hospitalizacija (28).

Matju (Mathieu) i saradnici (29) su u svom istraživanju pokazali da incidencija kasne UGT kontinuirano raste 
nakon RT, dostigavši nakon 10 godina $24 \%$ za gradus $\geq 2$ i $7 \%$ za gradus $\geq 3$, dok su Šmid (Schmid) i saradnici objavili da se simptomi UGT povlače nakon EBRT (20). Piters (Peeters) i saradnici (19) su pokazali da je kumulativni rizik za razvoj $R T O G / E O R T C$ UGT gradusa $\geq 2$ nakon 3 godine praćenja $28,5 \%$ za aplikovanu TD 68 Gy i 30,2\% za aplikovanu TD 78 Gy. Za gradus $\geq 3$ rizik je iznosio $5,1 \%$ u prvoj grupi i $6,9 \%$ u drugoj grupi, pri čemu nije bilo statistički značajne razlike u ukupnoj učestalosti toksičnosti između randomizovanih grupa, ali je incidencija kasne UGT bila viša u grupi koja je primila 78 Gy. Studija Balara (Ballare) i saradnika (30), objavljena nakon medijane od 30 meseci praćenja (20 - 50 meseci), pokazala je da se kasna UGT gradusa 1 manifestovala u $8,2 \%$ pacijenata, a gradusa 2 u $2 \%$ pacijenata, što može biti u vezi sa preporukom pacijentima za održavanje pune mokraćne bešike tokom svakog RT tretmana, čime se smanjuje volumen sluznice mokraćne bešike koji se nalazi u zračnom polju. Stanković i saradnici (25) su pokazali da DM može imati ulogu u razvoju kasne UGT, ali su neophodni dodatni parametri i duže praćenje pacijenata od onog zabeleženog u studiji, dok su Kalakota i saradnici (31) objavili visoku incidenciju kasne UGT gradusa $\geq 2$ kod pacijenata sa DM, kao i da primena doze $\geq 74$ Gy kod pacijenata sa DM ima potencirajući efekat na razvoj kasne UGT, čak i primenom IMRT. Takođe su ukazali da bi ova veza mogla biti korisna kada se razmatra lečenje pacijenata sa DM, posebno onih koji primaju veće doze zračenja ili onih pacijenata sa istorijom transuretralne resekcije prostate.

Viši gradusi akutne toksičnosti $(\geq 2)$ prediktori su pojave većih gradusa kasne UGT, što su potvrdili i rezultati istraživanja RT01 Odbora za medicinska istraživanja (engl. Medical Research Council RT01 Trial) (22), ali nema statistički značajne korelacije između kasne UGT i promene pražnjenja mokraćne bešike u odnosu na predterapijsko stanje.

\section{Zaključak}

Danas se rak prostate smatra hroničnom bolešću i poboljšanje kvaliteta života predstavlja važan cilj u lečenju ovih pacijenata. U savremenoj radioterapiji malignoma prostate se, kao zlatni standard, koriste napredne tehnike kao što su IMRT i VMAT, koje su omogućile eskalaciju doze, bolju lokalnu kontrolu bolesti, ali i smanjenje ranih i kasnih komplikacija zračnog tretmana. Pravilna selekcija pacijenata i optimalan individualizovan plan lečenja omogućiće redukciju očekivane radijacione toksičnosti i očuvanje kvaliteta života dugoživećih pacijenata sa karcinomom prostate.

Literatura

1. Christensen K, Doblhammer G, Rau R, Vaupel JW. Ageing populations: the challenges ahead. Lancet. 2009; 374(9696):1196-208.

2. U.S. Cancer Statistics Working Group. US cancer statistics: 19992009 incidence and mortality web-based report. Atlanta GA: USDHHS, CDC; 2013.

3. Bell KJ, Del Mar C, Wright G, Dickinson J, Glasziou P. Prevalence of incidental prostate cancer: A systematic review of autopsy studies. International Journal of Cancer. 2015; 137(7):1749-57.

4. Siegel RL, Miller KD, Jemal A. Cancer statistics, 2018. CA: A Cancer Journal for Clinicians. 2018; 68(1):7-30.

5. Wong MC, Goggins WB, Wang HH, Fung FD, Leung C, Wong SY et al. Global Incidence and Mortality for Prostate Cancer: Analysis of Temporal Patterns and Trends in 36 Countries. European Urology. 2016; 70(5):862-74.

6. Mottet N, van den Bergh RCN, Briers E, Cornford P, De Santis M, Fanti S et al. Prostate Cancer. European Association of Urology. 2020.

7. Michaelson MD, Cotter SE, Gargollo PC, Zietman AL, Dahl DM, Smith MR. Management of complications of prostate cancer treatment. CA: A Cancer Journal for Clinicians. 2008; 58(4):196-213.

8. Hoffman KE, Voong KR, Levy LB, Allen PK, Choi S, Schlembach PJ, et al. Randomized Trial of Hypofractionated, Dose-Escalated, Intensity-Modulated Radiation Therapy (IMRT) Versus Conventionally Fractionated IMRT for Localized Prostate Cancer. Journal of Clinical Oncology. 2018; 36(29):2943-9.

9. Mynderse A. L, Cummings T, King A. M, McDaniel K, Srnka C. Mayo Clinic Essential Guide to Prostate Health. 2015.

10. Brady L, Combs S, Lu J. Target Volume Delineation for Conformal and Intensity-Modulated Radiation Therapy. Heidelberg: Springer; 2015.

11. Halperin EC, Wazer DE, Perez CA, Brady LW, editors. Perez and Brady's principles and practice of radiation oncology. 7th edition. Philadelphia: Wolters Kluwer. 2018.

12. Cox JD, Stetz J, Pajak TF. Toxicity criteria of the radiation therapy oncology group RTOG and the European organization for research and treatment of cancer EORTC. International Journal of Radiation Oncology, Biology, Physics. 1995; 31(5):1341-6.

13. Serrano NA, Kalman NS, Anscher MS. Reducing rectal injury in men receiving prostate cancer radiation therapy: current perspectives. Cancer Management and Research. 2017; 9:339-50.

14. Fajardo LF. The pathology of ionizing radiation as defined by morphologic patterns. Acta Oncologica. 2005; 44(1):13-22.

15. Valdagni R, Rancati T, Fioriono C, Fellin G, Magli A, Baccolini $\mathrm{M}$, et al. Development of a set of nomograms to predict acute lower gastrointestinal toxicity for prostate cancer 3D-CRT. International Journal of Radiation Oncology, Biology, Physics. 2008; 71(4):1065-73.

16. Stankovic V, Nikitovic M, Pekmezovic T, Pekmezovic D, Kisic Tepavcevic D, Stefanovic Djuric A, et al. Toxicity of the lower gastrointestinal tract and its predictive factors after $72 \mathrm{~Gy}$ conventionally fractionated $3 \mathrm{D}$ conformal radiotherapy of localized prostate cancer. Journal of BUON. 2016; 21(5):1224-32.

17. Vavassori V, Fiorino C, Rancati T, Magli A, Fellin G, Baccolini M, et al. Predictors for Rectal and Intestinal Acute Toxicities During Prostate Cancer High-Dose 3D-CRT: Results of a Prospective Multicenter Study. International Journal of Radiation Oncology, Biology, Physics. 2007; 67(5):1401-10.

18. World Endoscopy Organization. Radiation proctitis. 2012.

19. Peeters STH, Heemsbergen WD, van Putten WLJ, Slot A, Tabak $\mathrm{H}, \mathrm{Mens} \mathrm{JW}$, et al. Acute and late complications after radiotherapy for prostatae cancer: Results of a multicenter randomized trial comparing 68 Gy to 78 Gy. International Journal of Radiation Oncology, Biology, Physics. 2005; 61(4):1019-34.

20. Schmid MP, Pötter R, Bombosch V, Sliivic S, Kirisits C, Dörr W, et al. Late gastrointestinal and urogenital side-effects after radiotherapy - Incidence and prevalence. Subgroup-analysis within the prospective Austrian - German phase II multicenter trial for localized prostate cancer. Radiotherapy and Oncology. 2012; 104(1):114-8.

21. Barnett GC, De Meerleer G, Gulliford SL, Sydes MR, Elliott RM, Dearnaley DP. The impact of Clinical Factors on the Development of Late Radiation Toxicity: Results from the Medical Research Council RT01 Trial (ISRCTN47772397). Clinical oncology 2011; .23(9):613-24.

22. Mak RH, Hunt D, Shipley WU, Jones CU, Lukka HR, Bahary JP, et al. Acute and Late Urinary Toxicity After Radiation Therapy in Men With and Without an Intact Prostate Gland: A Secondary 
Analysis of RTOG 9408 and 9601 Suggesting This Toxicity is Not Due to Bladder Injury. International Journal of Radiation Oncology, Biology, Physics. 2012; 84(3):S14.

23. Michalski JM, Purdy JA, Winter K, Roach III M, Vijayakumar S, Sandler HM, et al. Preliminary report of toxicity following 3D radiation therapy for prostate cancer on 3DOG/RTOG 9406. International Journal of Radiation Oncology, Biology, Physics. 2000; 46(2):391-402.

24. Pinkawa M, Fischedick K, Asadpour B, Gagel B, Piroth MD, Nussen $\mathrm{S}$, et al. Toxicity profile with a large prostate volume after external beam radiotherapy for localized prostate cancer. International Journal of Radiation Oncology, Biology, Physics. 2008; 70(1):83-9.

25. Stankovic V, Džamic Z, Pekmezovic T, Kisic Tepavcevic D, Dozic M, Saric M, et al. Acute and Late Genitourinary Toxicity after 72 Gy of Conventionally Fractionated Conformal Radiotherapy for Localised Prostate Cancer: Impact of Individual and Clinical Parameters. Clinical Oncology 2016; 28(9):577-86.

26. Widmark A, Fransson P, Tavelin B. Self-assessment questionnaire for evaluating urinary and intestinal late side effects after pelvic radiotherapy in patients with prostate cancer compared with an age-matched control population. Cancer. 1994; 74(9):2520-32.
27. Sandhu AS, Zelefsky MJ, Lee HJ, Lombardi D, Fuks Z, Leibel SA. Long-term urinary toxicity after 3-dimensional conformal radiotherapy for prostate cancer in patients with prior history of transurethral resection. International Journal of Radiation Oncology, Biology, Physics. 2000; 48(3):643-7.

28. Lawton CA, Won M, Pilepich MV, Asbel SO, Shipley WU, Hanks $\mathrm{GE}$, et al. Long-term treatment sequelae following external beam irradiation for adenocarcinoma of the prostate: analysis of RTOG studies 7506 and 7706. International Journal of Radiation Oncology, Biology, Physics. 1991; 21(4):935-9.

29. Mathieu R, Arango JDO, Beckendorf V, Delobel J-B, Messai T, Chira C, et al. Nomograms to predict late urinary toxicity after prostate cancer radiotherapy. World Journal of Urology. 2014; 32(3):743-51.

30. Ballare A, Di Salvo M, Loi G, Ferrari G, Beldi D, Krengli M. Conformal radiotherapy of clinically localized prostate cancer: analysis of rectal and urinary toxicity and correlation with dose-volume parameters. Tumori. 2009; 95(2):160-8.

31. Kalakota K, Liauw SL. Toxicity after external beam radiotherapy for prostate cancer: an analysis of late morbidity in men with diabetes mellitus. Urology. 2013; 81(6):1196-201. 